\title{
DETERMINING THE NEGATIVE EFFECT ON HOUSE VALUES OF PROXIMITY TO A LANDFILL SITE BY MEANS OF AN APPLICATION OF THE HEDONIC PRICING METHOD
}

\author{
M du Preez \\ Department of Economic History, Nelson Mandela Metropolitan University
}

T Lottering

Aberdare Power Cables, Port Elizabeth

\begin{abstract}
This study applied the hedonic pricing method to determine whether a disused, solid waste landfill site has an adverse effect on the prices of low-cost houses in New Brighton, a neighbourhood of the Nelson Mandela Metropole, Eastern Cape, South Africa. The results of the study show that the landfill site has a negative effect on New Brighton house prices. The average increase in house value is R36.00 per one hundred metres from the landfill site. This increase amounts to 0.44 percent of the value of a house per 100 metres from the landfill. When the change in value is summed for all the properties in the sample area (allowing for variation in value change due to differing distances from the landfill site) the total disamenity effect of the landfill site is approximately R1.4 million.

JEL Q57
\end{abstract}

\section{1 \\ Introduction}

Whether, and to what degree, solid waste landfills have an adverse effect on residential property prices has received a great deal of attention over the years (see, for example, Bouvier, Halstead, Conway \& Manalo, 2000; Havlicek, Richardson \& Davies, 1971; Reichert, 1991). It is a well-recognised fact that the establishment and operation of a landfill creates negative externalities, which may include environmental damages, such as the build-up of methane gas and groundwater contamination (Lomberg, Rosewarne, Raymer \& Devey, 1996; Reddy \& Gardiner, 2003). In addition to these damages, the dumping of solid waste may also give rise to bad odors, vermin and flies, while litter may spread from the landfill if it is not properly policed (Bouvier et al., 2000). Moreover, covering and compacting the solid waste with soil creates airborne dust. As a result of these negative impacts, it is normal to locate landfills that may have a deleterious aesthetic and health impact on areas remote from residential neighbourhoods, as well as creating buffer zones to prevent further encroachment.

The economic impact of a landfill on the value of properties situated in close proximity to it is important for a number of reasons. First, price disparities between like properties, differing only in their distance from a landfill, provide information on the welfare effect on households situated in the vicinity (Ready, 2005). Second, affected property owners want to know what effect, if any, the presence of a landfill has or will have on the value of their assets. Third, in the event of a landfill project being subject to cost-benefit analysis, estimates of property price effects can be incorporated into the cost-benefit profile.

Numerous studies have been conducted to determine an empirical relationship between residential property prices and proximity to a solid waste landfill site (Ready, 2005). The hedonic pricing method, which entails drawing 
inferences from markets where it is believed preferences for environmental goods are captured, was used in these studies to estimate the abovementioned relationship.

Most of these studies have found a negative relationship between residential house prices and proximity to a landfill (see, for example, Nelson, Generoux \& Generoux, 1992; Havlicek, Richardson \& Davies, 1971; Havlicek, 1985; Adler, Cook, Ferguson, Vickers, Anderson \& Dower, 1982; Baker, 1982). More specifically, these studies show that the values of residential properties situated within a four-mile radius of a landfill site rise by between 5 and 7 percent per mile (i.e. $1.6 \mathrm{~km}$ ) distance away from the site. No negative value effects were found for properties located in excess of four miles from the landfill. However, property values fall more dramatically (i.e. between 21 and 30 percent) the closer (i.e. within a quarter to a half mile radius) the properties are situated to a landfill site. On the other hand, a few studies have found that no statistically significant relationship exists between house prices and proximity to a landfill (see, for example, Gamble, Downing, Shortle \& Epp, 1982; Zeiss \& Atwater, 1989; Bouvier et al., 2000).

There is a paucity of South African studies which explore the negative effects of proximity to landfill sites on the value of residential properties. The purpose of this paper is to derive a measure for the reduction in house value in rands due to proximity to a landfill site, by means of an application of the hedonic pricing method.

\section{2}

\section{Methodology}

The theory underlying the economic rationale for employing the hedonic pricing method to analyse residential house prices is couched in the work of Rosen (1974). The hedonic pricing method relies on the principle that a person's utility is based on the characteristics of the good consumed. In the context of the housing market, the characteristics theory of consumer choice hypothesises that the purchase price a potential buyer is willing to pay is dependent upon the broad range of characteristics of the house, for example physical characteristics (such as house size, age, number of rooms), location characteristics (such as proximity to amenities like schools and shopping centres), and environmental quality variables (such as the quality of the air, noise pollution, and proximity to a landfill).

The application of the hedonic pricing method requires the collection of information on all the factors determining the price of a house. Once this has been done, the conventional hedonic pricing method continues in two steps: first, a hedonic (or implicit) price function is estimated; second, a demand curve is estimated for some environmental quality component (Hanley \& Spash, 1993).

The derivation of the hedonic price function entails estimating an empirical relationship between the market price of a particular residential property and the levels of its characteristics or attributes. This function portrays the equilibrium collection of property values, given the house-purchasing population and the obtainable housing supply (Ready, 2005). Formally, the hedonic pricing function can be defined as follows:

$\mathrm{P}_{h}=\mathrm{P}\left(\mathrm{C}_{i}, \mathrm{~L}_{j}, \mathrm{E}_{k}\right) ;[\mathrm{i}=1 . . \mathrm{f}, \mathrm{j}=1 . . \mathrm{g}, \mathrm{k}=1 . . \mathrm{h}]$

where:

$\mathrm{P}$ represents the house prices in an urban area of interest;

C represents the physical characteristics;

L represents the location characteristics; and

E represents the environmental characteristics (Hanley \& Spash, 1993).

Equation (1) can be expected to be nonlinear, because consumers are unable to treat individual housing characteristics as discrete components from which they can choose until the required composite of characteristics is found (Rosen, 1974). The implicit price of an individual characteristic or amenity can be found by partially differentiating Equation (1) with respect to that individual characteristic (Hanley \& Spash, 1993).

The conventional way of determining the effect of a solid waste landfill site on house prices is to incorporate a certain continuous 
measure of proximity to a landfill site into the hedonic price function. For instance, assuming that $\mathrm{E}$ in Equation (1) represents solely the proximity to a landfill site, then its implicit price would be:

$$
\left(\mathrm{P}_{h} /\left(\mathrm{E}_{k}=\left(\mathrm{P}\left(\mathrm{C}_{i}, \mathrm{~L}_{j}, \mathrm{E}_{k}\right) /\left(\mathrm{E}_{k}\right.\right.\right.\right.
$$

The expression $\left(\mathrm{P}_{h} /\left(\mathrm{E}_{k}\right.\right.$ provides an estimate of a household's marginal willingness-to-pay for a change in distance from a landfill site. This expression can therefore be viewed as the incremental increase in the value of a house for a one-unit increase in distance from the landfill site, assuming that there is a positive relationship between distance and price (Van Kooten Bulte, 2001).

The second stage of the hedonic price model is based on Rosen's (1974) work on implicit markets and requires that the compensated demand curve for the environmental variable in question be estimated. Using this demand curve, the consumer surplus can be calculated.

The rest of this paper is structured as follows: Section 3 describes the data and methods used in the study, Section 4 reports the results of the study, Section 5 provides a discussion of the results, and Section 6 provides a short conclusion.

\section{3}

\section{Data and methods}

\subsection{The study area}

The study area is the New Brighton neighbourhood located in the Nelson Mandela Metropole, Eastern Cape, South Africa. The majority of the houses in this area can be classified as low-cost housing. One solid waste landfill site is included in the study, namely the Ibhayi landfill site. This site was used as a landfill from 1981 to 2001, and accepted waste mostly from the Nelson Mandela Metropolitan Municipality (NMMM). The total amount of solid waste dumped at this site was approximately 20000 tons per month (Horn, 2005). The site is presently under the control of the NMMM.

The landfill is not physically isolated from the surrounding formal residential area (i.e. New
Brighton). Formal residential housing is located adjacent to the eastern and northern sides of the landfill border. An informal settlement of shack dwellers is located to the west of the landfill (the shacks are erected on vacant areas and are not registered properties), and no formal housing is found to the south of the landfill border. These areas do not constitute part of the survey.

The formal residential area has a high housing density and an equally high population density. More specifically, population density is in excess of 12000 per square kilometre with an average occupancy of four per household (Census, 2001). The mean erf size for the area is 246 square metres (Horn, 2005).

\subsection{Data}

To compile data on the houses located in the formal residential area (i.e. New Brighton) and situated adjacent to the Ibhayi landfill site, the GIS database was used. The database was supplied to estate agents for the purposes of valuing properties in the Nelson Mandela Metropole. Municipal street maps were then used to identify, by means of an erf number, those houses that were situated within two kilometers of the landfill site. ${ }^{1}$ The rationale for setting a two kilometre limit was that this is the limit of formal housing to the east of the landfill site, at which point it gives way to an industrial area. A total number of 40000 housing units were identified, from which a representative sample of 496 houses was selected. This sample generates an error of less than 4.5 percent at a 95 percent confidence level. For each house identified in the sample, the following data were collected: the value of the property (at 2005 price levels), the erf size, the building size, and the existence or lack of outbuildings. Based on the location of the relevant properties, straight-line distances from the landfill site were calculated.

The residences situated adjacent to the landfill site in the township (New Brighton) are primarily low-cost units and the property market for this area is not well developed. Owing to a paucity of market transaction data, property valuations conducted by municipal officials and independent property evaluators were used as 
house prices. The differences in these valuations reflect municipal perceptions of the relative market worth of the relevant properties at a given point in time.

\subsection{The hedonic pricing model}

As noted in the discussion of the methodology of the hedonic pricing method (see Section 2), to determine the effect on house values, if any, of proximity to a landfill site, it is necessary to develop a statistical function (i.e. the hedonic price function) that accurately reflects the magnitude of the effect that a range of explanatory variables, including the proximity to landfill issue, have on the dependent variable, namely house values. For the purposes of this study the following hedonic price function was specified:
Value $=\beta_{0}+\beta_{1}($ Erfsize $)+\beta_{2}($ Sizebuild $)$

$+\beta_{3}($ Outbuild $)+\beta_{4}($ Distance $)+u$

where:

Value denotes the house price in Rands;

Erf size indicates the size of the erf in $\mathrm{m}^{2}$;

Sizebuild denotes the size of the main building in $\mathrm{m}^{2}$;

Outbuild refers to the presence or lack of outbuildings;

Distance refers to the distance of the property from the landfill; and

$\mathrm{u}$ represents the error term.

A description of the abovementioned variables, their operational definitions, and their hypothesised sign, are provided in Table 1 below.

\section{Table 1}

Variables included in the hedonic price function

\begin{tabular}{|l|l|l|}
\hline Dependent variable & Operational definition & Hypothesised sign \\
\hline Value (Rand) & Continuous variable & \\
\hline Independent variables & Operational definition & Hypothesised sign \\
\hline Size of erf $\left(\mathrm{m}^{2)}\right.$ & Continuous variable & Positive \\
\hline Size of main building $\left(\mathrm{m}^{2}\right)$ & Continuous variable & Positive \\
\hline Outbuildings & Dummy variable & Positive \\
\hline Distance from landfill $(\mathrm{m})$ & Continuous variable & Positive \\
\hline
\end{tabular}

\section{Results}

Analysis of the house value statistic reveals that, on average, the houses in the study area have a value of $\mathrm{R} 8$ 505.34. The statistics relating to the house value variable are shown in Table 2 below.

\section{Table 2}

Analysis of the house value statistic in the hedonic price function

\begin{tabular}{|l|c|c|c|c|c|}
\hline Variable & $\begin{array}{c}\text { Mean } \\
\text { (Rand) }\end{array}$ & $\begin{array}{c}\text { Std Dev } \\
\text { (Rand) }\end{array}$ & $\begin{array}{c}\text { Min } \\
\text { (Rand) }\end{array}$ & $\begin{array}{c}\text { Median } \\
\text { (Rand) }\end{array}$ & $\begin{array}{c}\text { Max } \\
\text { (Rand) }\end{array}$ \\
\hline House Value & R8505.34 & R3341.00 & R1410.00 & R7630.00 & R23810.00 \\
\hline
\end{tabular}

A statistical analysis of the explanatory variables used in the hedonic price function is provided in Table 3 below. 


\section{Table 3}

Descriptive statistics of explanatory variables in the hedonic price function

\begin{tabular}{|l|c|c|c|c|c|}
\hline Variable & $\begin{array}{c}\text { Mean } \\
\text { (Rand) }\end{array}$ & $\begin{array}{c}\text { Std Dev } \\
\text { (Rand) }\end{array}$ & $\begin{array}{c}\text { Min } \\
(\text { Rand) }\end{array}$ & $\begin{array}{c}\text { Max } \\
\text { (Rand) }\end{array}$ & $\begin{array}{c}\text { Median } \\
\text { (Rand) }\end{array}$ \\
\hline Erf size & $228.85 \mathrm{~m}^{2}$ & $30.94 \mathrm{~m}^{2}$ & $148.00 \mathrm{~m}^{2}$ & $405.00 \mathrm{~m}^{2}$ & $228.00 \mathrm{~m}^{2}$ \\
\hline Building size & $61.33 \mathrm{~m}^{2}$ & $23.59 \mathrm{~m}^{2}$ & $0.00 \mathrm{~m}^{2}$ & $195.10 \mathrm{~m}^{2}$ & $53.30 \mathrm{~m}^{2}$ \\
\hline Outbuilding & 0.455 & 0.498 & 0.00 & 1.00 & 0.00 \\
\hline Distance from landfill & $710.16 \mathrm{~m}$ & $658.52 \mathrm{~m}$ & $10.00 \mathrm{~m}$ & $2000.00 \mathrm{~m}$ & $550.00 \mathrm{~m}$ \\
\hline
\end{tabular}

The results of the estimation of the hedonic price function (Equation 3) are shown in Table 4 below.

\section{Table 4}

Estimation results of the hedonic price function $(n=496)$

\begin{tabular}{|c|c|c|c|c|}
\hline \multicolumn{5}{|c|}{$\begin{array}{l}\text { Dependent variable: House value (Rand) } \\
\mathrm{R}^{2}=0.869 \\
\text { Adj. } \mathrm{R}^{2}=0.868\end{array}$} \\
\hline Variable & $\begin{array}{l}\text { Estimated } \\
\text { coefficient }\end{array}$ & $\begin{array}{c}\text { Standard } \\
\text { error }\end{array}$ & t-statistic & P-value \\
\hline Intercept & -957.25 & 431.13 & -2.22 & 0.0269 \\
\hline Erf size & 4.72 & 2.02 & 2.34 & 0.02 \\
\hline Building size & 125.71 & 3.60 & 34.94 & 0.0000 \\
\hline Outbuildings & 908.44 & 111.86 & 8.12 & 0.0000 \\
\hline Distance from landfill & 0.36 & 0.08 & 4.26 & 0.0000 \\
\hline
\end{tabular}

The data set generated an $\mathrm{R}^{2}$ of 0.869 and an adjusted $\mathrm{R}^{2}$ of 0.868 , which attests to the model's predictive power. All the estimated coefficients are statistically highly significant and have the hypothesised sign. When the mean values for all the explanatory variables (except that of the distance from landfill) obtained in the analysis are substituted into the estimated hedonic price function (see Equation 3), the following equation results:

Value $=8246.03+0.36($ Distance $)$

\section{5}

\section{Discussion}

The results obtained above show that the Ibhayi landfill site has a negative effect on New
Brighton house prices. More specifically, the average increase in house value is R36.00 per one hundred metres from the landfill site (see Equation 4 above). Based on the assumption that the value of a property adjacent to the landfill border is R8 246.03 and that a property located two thousand metres away has a value of R8 966.03, the effect of proximity to the landfill site is to reduce the value of a house by a maximum of R720.00 (two thousand metres is the easterly limit of housing in the New Brighton neighbourhood). Stated differently, house prices increase by 0.44 percent if the houses are situated 100 metres away instead of adjacent to the landfill border, and by 8.73 percent if they are 2000 metres away instead of adjacent to the site. If the change in value is summed for all the properties in the sample 
area (allowing for variation in value change due to differing distances from the landfill site) the total disamenity effect of the landfill site is approximately R1.4 million.

A number of restrictive assumptions surrounding this type of analysis must, however, be borne in mind. First, the hedonic pricing method only provides accurate estimations of the value of environmental quality if perfect information exists in the market (i.e. all buyers in the housing market have perfect information on the environmental quality variables at every conceivable location). This assumption is, however, not met in reality if people's awareness of the landfill site is based on inaccurate information or lack of knowledge (Bouvier et al., 2000). For example, if a landfill site poses a serious health risk, individuals may not be aware of either its extent or its potential impact on house values.

Second, the assumption regarding zero transaction costs is also not borne out in reality (Bouvier et al., 2000). Many individuals who reside in close proximity to a landfill site may be disturbed by the potential health risks it poses, but relocation costs may be prohibitively expensive. This often outweighs the incremental benefits derived from being situated further away from the landfill site.

In summary, the results of this study do not permit wide-ranging generalisations regarding the effect of a landfill site on house prices in South Africa. The landfill considered in this study has been inoperative since 2001, and the adjacent neighbourhood is one where low-cost housing dominates.

\section{6}

\section{Conclusion}

Many studies on hedonic pricing have shown that property prices increase with a move away from a landfill site. A few studies have shown that the impact of landfill sites on house values is negligible. There is, however, a paucity of similar studies conducted in South Africa. This study applied the hedonic pricing method to estimate the loss, if any, of property value due to the disamenity created by proximity of low-cost housing to a solid waste landfill site (the Ibhayi site) located in New Brighton, Nelson Mandela Metropole, Eastern Cape.

A regression analysis was performed to obtain a statistical function (i.e. the hedonic price function) that depicts the empirical relationship between property values and distance from the landfill. Other housing characteristics were also included in the hedonic price model, such as erf size, house size, and the existence or absence of outbuildings.

The results obtained show that the Ibhayi landfill site has a negative effect on New Brighton house prices. More specifically, the average increase in house value is R36.00 per one hundred metres from the landfill site. Stated differently, house prices increase by 0.44 percent per 100 metres from the landfill. When this change in value is summed for all the properties in the sample area (allowing for variation in value change due to differing distances from the landfill site) the total disamenity effect of the landfill site is approximately R1.4 million.

The results suggest a need for more considered residential planning, particularly in low-income areas. More specifically, solid waste landfill sites that may have deleterious aesthetic, health and economic impacts should, ideally, be located far from residential neighbourhoods or, at the very least, buffer zones should be created to prevent further encroachment. In the case of the Ibhayi landfill, the NMMM should endeavor to keep the disused landfill site as tidy as possible, and monitor it on a regular basis so as to safeguard the values of properties situated adjacent to it.

\section{Acknowledgements}

The helpful comments and suggestions made by the anonymous referees are gratefully acknowledged.

\section{Endnote}

1 Convention suggests an upper bound of two miles (3.6 kilometers) of the area affected by landfill (Nelson et al., 1992). 


\section{References}

ADLER, K.J., COOK, Z.L., FERGUSON, A.R., VICKERS, M.J., ANDERSON, R.C. \& DOWER, R.C., 1982. The benefits of regulating hazardous disposal: land values as an estimator. Washington D.C.: US Environmental Protection Agency.

BAKER, B.P., 1982. Land values and surrounding waste disposal facilities. Department of Agricultural Economics, New York College of Agriculture and Life Sciences, Cornell University, Ithaca, New York. BOUVIER, R.A., HALSTEAD, J.M., CONWAY, K.S. \& MANALO, A.B., 2000. The effects of landfills on rural residential property values: some empirical analysis. Journal of Regional Analysis and Policy, 30:(2): 23-37.

CENSUS 2001. Census of Population Density in the NMMM. http://www.statssa.gov.za/census2001.

(Accessed: 18th August 2007).

GAMBLE, H.B., DOWNING, R.H., SHORTLE, J. \& EPP, D.J., 1982. Effects of solid waste disposal sites on community developments and residential property values. Institute for Research on Land and Water Resources, Pennsylvania State University.

HANLEY, N. \& SPASH, C., 1993. Cost-benefit analysis and the environment. Vermont: Edward Elgar Publishing Ltd.

HAVLICEK, J., 1985. Impacts of solid waste disposal sites on property values, In: Tolley, G.S., Havlicek, J. \& Favian, R. (Eds). Environmental policy: solid waste, 4. Cambridge, MA: Ballinger.

HAVLICEK, J., RICHARDSON, R. \& DAVIES, L., 1971. Measuring the impacts of solid waste disposal site location on property values. American Journal of Agricultural Economics, 53: 869.

HORN, C., 2005. Personal communication. Manager: Nelson Mandela Metropolitan Municipality, Port Elizabeth.

LOMBERG, C.R., ROSEWARNE, P.N., RAYMER, D.A. \& DEVEY, D.G., 1996. Research into groundwater abstraction in the Port Elizabeth municipal area. Pretoria: Water Research Commission, Report No. 515/1/97.

NELSON, A.C., GENEROUX, J. \& GENEROUX, M., 1992. Price effects of landfills on house values. Land Economics, 68: 359-365.

READY, R.C., 2005. Do landfills always depress nearby property values? Rural Development Paper, No. 27. The Northeast Regional Center for Rural Development. Pennsylvania State University. REDDY, V.S. \& GARDINER, R., 2003. Air dispersion modeling and assessment of risks associated with landfill gas emissions from the Ibhayi landfill site. SRK Consulting Engineers and Scientists, Port Elizabeth. REICHERT, A.K., 1991. The impact of landfills on residential property values. Cleveland, $\mathrm{OH}$.: Cleveland State University.

ROSEN, S., 1974. Hedonic prices and implicit markets: product differentiation in pure competition. Journal of Political Economy, 82: 34-55.

VAN KOOTEN, G.C. \& BULTE, E., 2001. The economics of nature: managing biological assets. Boston: Blackwell Publishers Ltd..

ZEISS, C. \& ATWATER, J., 1989. Waste facility impacts on residential property values. Journal of Urban Planning and Development, 15: 64-80. 